\title{
MEMBANGUN MOTIVASI BELAJAR MELALUI PEMBELAJARAN AKTIF DAN PENGGUNAAN KOMIK BERBASIS DISCOVERY LEARNING
}

\author{
ACHMAD SYAHREZA
}

SMP Islam Integral Luqman Al Hakim Batam

e-mail: achmadsyahreza21@guru.smp.belajar.id

\begin{abstract}
ABSTRAK
Belajar di masa pandemi covid-19 memberi dampak bagi peserta didik, diantaranya ialah penurunan motivasi belajar. Kondisi ini merupakan tantangan bagi guru, dan hal ini membuka pintu untuk menemukan solusi atas persoalan yang muncul. Salah satu upaya yang dilakukan ialah pembelajaran aktif dan penggunaan komik berbasis discovery learning. Metode penelitian ini disusun dan dilakukan dengan pendekatan kualitatif deskriptif melalui studi kasus. Data yang diperoleh dari studi literatur sebagai data sekunder, adapun data primer diperoleh dari wawancara, angket, observasi, dan dokumentasi. Dalam penerapannya diperoleh hasil yang sesuai dengan apa yang diharapkan, berdasarkan hasil wawancara dan angket bahwa pembelajaran aktif dan penggunaan komik mendorong motivasi belajar peserta didik. Oleh karena itu, pembelajaran aktif dan penggunaan komik yang diteliti dengan pendekatan kualitatif deskriptif dalam studi kasus mampu membangun motivasi belajar siswa pada masa pandemi covid-19 di SMP Islam Integral Luqman Al Hakim, Kota Batam.
\end{abstract}

Kata Kunci: Motivasi, Pembelajaran Aktif, Komik

\section{PENDAHULUAN}

Masa pandemi covid-19 memberi pengaruh terhadap pendidikan di berbagai tingkatan. Ada banyak masalah yang muncul, baik secara materiil, maupun nonmateriil. Kedua hal ini berpengaruh terhadap keberhasilan peserta didik dalam meraih tujuan belajar. Diantara faktor nonmateriil ialah motivasi, dari segi bahasa, kata motivasi berarti dorongan yang timbul pada diri seseorang secara sadar atau tidak sadar untuk melakukan suatu tindakan dengan tujuan tertentu ("motivasi". KBBI Daring, 2016. Web. 13 Sep 2021). Dalam bahasa arab diistilahkan dengan himmah yaitu dorongan kuat untuk melakukan sesuatu (Anis, 2004: 996).

Motivasi akan mendorong lahirnya energi besar untuk melakukan berbagai kegiatan belajar dalam meraih tujuan pembelajaran. Oleh karena itu, diperlukan upaya untuk membangkitkan motivasi belajar yang akan melahirkan energi untuk melakukan berbagai kegiatan pembelajaran, sehingga meraih tujuan yang direncanakan. Menurut Mudjiman (2007: 43) diantara faktor yang mempengaruhi terbentuknya motivasi belajar ialah faktor pelaksanaan kegiatan belajar.

Berdasarkan uraian di atas, maka diambil satu upaya yaitu dengan menerapkan pembelajaran aktif dan penggunaan bahan ajar komik. Pembelajaran aktif ialah serangkaian aktivitas yang memberikan kesempatan besar kepada peserta didik untuk terlibat dalam proses dan pencapaian tujuan pembelajaran. Belajar aktif dan penggunaan media belajar sendiri pernah dicontohkan oleh Nabi Muhammad (Abu Ghuddah, 1996). Nabi Muhammad sangat menganjurkan hadirnya pembelajaran yang aktif, yakni peserta didik aktif mendengar, mencatat atau menghafal apa-apa yang didengar, mengkaitkan suatu masalah dengan pengetahuan yang telah dimiliki untuk dinilai atau dihukumi, dan mengkomunikasikannya agar mendapatkan respon dari pendengar (at-Tirmidziy, 2011: 483). Komik sendiri ialah media komunikasi visual yang menyampaikan informasi secara populer yang terdiri dari gambar dan tulisan yang disusun berdasarkan alur cerita tertentu sehingga dapat membantu pembaca memahami pesan-pesan di dalamnya (Waluyanto, 2003: 51). Menurut penelitian juga dikatakan bahwa penggunaan komik dapat meningkatkan hasil belajar karena peserta didik menjadi tertarik dan aktif (Ernawati dan Sari, 2010: 34)

Dalam pembelajaran Ilmu Pengetahuan Alam di SMP Islam Integral Luqman Al Hakim teknik pembelajaran aktif dan penggunaan media komik dilakukan dengan model pembelajaran 
Discovery Learning. Penerapan teknik ini diawali dengan guru mempersiapkan bahan ajar yang didalamnya tersedia komik dan latihan soal mandiri, dan dibagikan sebelum pembelajaran di kelas berlangsung, kemudian saat pembelajaran di kelas agenda kegiatan sebagaimana urutan kegiatan belajar model Discovery Learning dan tentunya pembelajaran aktif mengharuskan keterlibatan peserta didik dari awal hingga akhir pembelajaran. Dengan diterapkannya upaya ini secara maksimal, motivasi belajar peserta didik terbangun dan meningkatnya kualitas pembelajaran Ilmu Pengetahuan Alam di SMP Islam Integral Luqman Al Hakim pada kompetensi dasar yang diajarkan.

\section{METODE PENELITIAN}

Pendekatan dalam penelitian ini ialah pendekatan kualitatif melalui studi kasus. Penelitian kualitatif sendiri ialah penelitian yang menghasilkan data deskriptif kata-kata tertulis atau lisan dari orang-orang dan tindakan yang bisa diamati (Eri Barlian, 2016). Penelitian ini memusatkan diri pada unit yang tunggal, maksudnya satu pihak atau kelompok tertentu yang padanya kasus itu melekat. Alasan penggunaan metode ini ialah untuk memahami apa yang menjadi hakikat dari suatu kejadian yang di beberapa kesempatan sulit dimengerti. Data kualitatif yang disajikan tentunya bersifat deskriptif, informatif dan berupa uraian tulisan.

Sumber data dalam penelitian ini ialah data primer dan data sekunder. Data primer berupa data dari sumber pertama, yang diperoleh dari peserta didik kelas 9A hingga 9E yang mengikuti pembelajaran aktif dan menggunakan media komik sains, 2 remaja yang bukan peserta didik tapi pembaca komik, 3 orang guru di SMP Islam integral Luqman Al Hakim. Adapun data sekunder didapat dari mempelajari literatur yang berhubungan dengan topik penelitian. Data yang dikumpulkan peneliti berupa wawancara, angket, obeservasi dan dokumentasi. Teknik analisis data yang digunakan dalam analisis kualitatif di sini terdiri dari empat langkah, yaitu pengumpulan data, reduksi data, penyajian data, dan penarikan kesimpulan yang disertai verifikasi. Adapun langkah-langkah kegiatannya bermula dari persiapan, pelaksanaan dan penyusunan.

\section{HASIL DAN PEMBAHASAN}

Tahapan pengumpulan data sekunder berupa studi literatur yang berhubungan dengan topik penelitian. Hasil yang diperoleh berupa informasi mengenai pembelajaran aktif, penggunaan bahan ajar komik dan motivasi yang diperoleh dari buku dan jurnal. Dari pengamatan langsung, diperoleh informasi bahwa peserta didik kelas IX senang membaca tulisan bergambar, dan pada pembelajaran IPA metode ceramah masih mendominasi dan belum menggunakan bahan ajar komik pada pembelajaran sebelumnya, sehingga pembelajaran aktif dan penggunaan komik menjadi inovasi baru di SMP Islam Integral Luqman Al Hakim Batam.

Berdasarkan observasi terhadap pembelajaran peserta didik menunjukkan bahwa peserta pasif dalam pembelajaran, beberapa siswa didapati tidur di kelas, tidak merespon tanya jawab dari guru kecuali 1 atau 2 orang saja. Hasil studi ini menunjukkan bahwa inovasi baru yang membangkitkan motivasi dan pembelajaran aktif menjadi sangat relevan untuk direalisasikan.

Bahan ajar komik dipersiapkan dari segi design, alur cerita, dan latar belakang lingkungan yang sesuai dengan nuansa sekolah. Materi yang disajikan ialah sistem reproduksi. Tahap I terdiri dari penyusunan naskah bahan ajar, RPP pembelajaran berbasis Discovery Learning dengan kegiatan pembelajaran berpusat pada peserta didik, dan kisi-kisi instrumen observasi dan angket yang berhubungan dengan aspek motivasi. Tahap II meliputi pembuatan bahan ajar komik dengan menggunakan fasilitas yang ada di pixton.com. Tahap III merupakan penilaian yang diberikan oleh 2 remaja yang suka membaca komik, masukan yang diberikan digunakan untuk melakukan refleksi dan perbaikan terhadap komik sebagai bahan ajar. Selain penilaian diberikan oleh 2 remaja, juga diberikan oleh 3 orang guru yang dengannya juga dijadikan masukan untuk perbaikan komik. Tahap IV adalah penyelesaian dan pencetakan di kertas berukuran A5 yang kemudian diperbanyak sejumlah peserta didik yang akan menggunakannya. 
Kegiatan pembelajaran dilakukan melalui 3 tahap. Tahap I ialah mempersiapkan prasayat pengetahuan dengan membagikan bahan ajar yang disertai dengan soalan untuk mengetahui peserta membaca dan menangkap informasi penting yang disajikan dalam komik, serta mencatat informasi tersebut di buku tulis. Tahap II ialah rangkaian kegiatan belajar aktif dengan urutan pembelajaran Discovery Learning yang peserta didik dilengkapi bahan ajar komik dan LKPD (Lembar Kerja Peserta Didik). Di dalam proses pembelajaran peserta didik terlibat aktif dalam mengidentifikasi masalah dari fakta yang diamati, kemudian mencatat dan mengemukakan hasilnya, setelah itu peserta didik mengumpulkan data dan mengolah data tersebut untuk memberikan jawaban sementara atas persoalan yang telah diidentifikasi, dan menyampaikannya bersamaan dengan proses verifikasi oleh sesama teman dan guru. Dan kegiatan dilanjutkan dengan membuat dan menyampaikan kesimpulan dari hasil pembelajaran. Tahap III peserta didik yang menggunakan komik sebagai bagian dari bahan belajarnya melakukan refleksi terhadap proses pembelajaran dan memberikan penilaian yang dituangkan dalam lembaran refleksi dan angket.

Komik dinilai oleh 2 remaja penyuka komik, dan 3 orang guru, penilaiannya diungkapkan secara lisan bahwa komik yang digunakan sebagai bahan ajar sudah mencerminkan lingkungan sekolah dengan peserta didik yang aktif, design sederhana tapi menarik, namun ukuran tulisan kecil, dan ini telah dilakukan perbaikan pada tahap III, sehingga kemudian komik dicetak. Penilaian komik sebagai bahan ajar yang diberikan peserta didik, yang terdiri dari 5 kelas, dengan jumlah 151 anak. Sekitar 147 anak memberikan jawaban komik menarik dan mereka termotivasi dalam belajar, ada sekitar 3 anak tidak memberikan, dan 1 biasa saja.

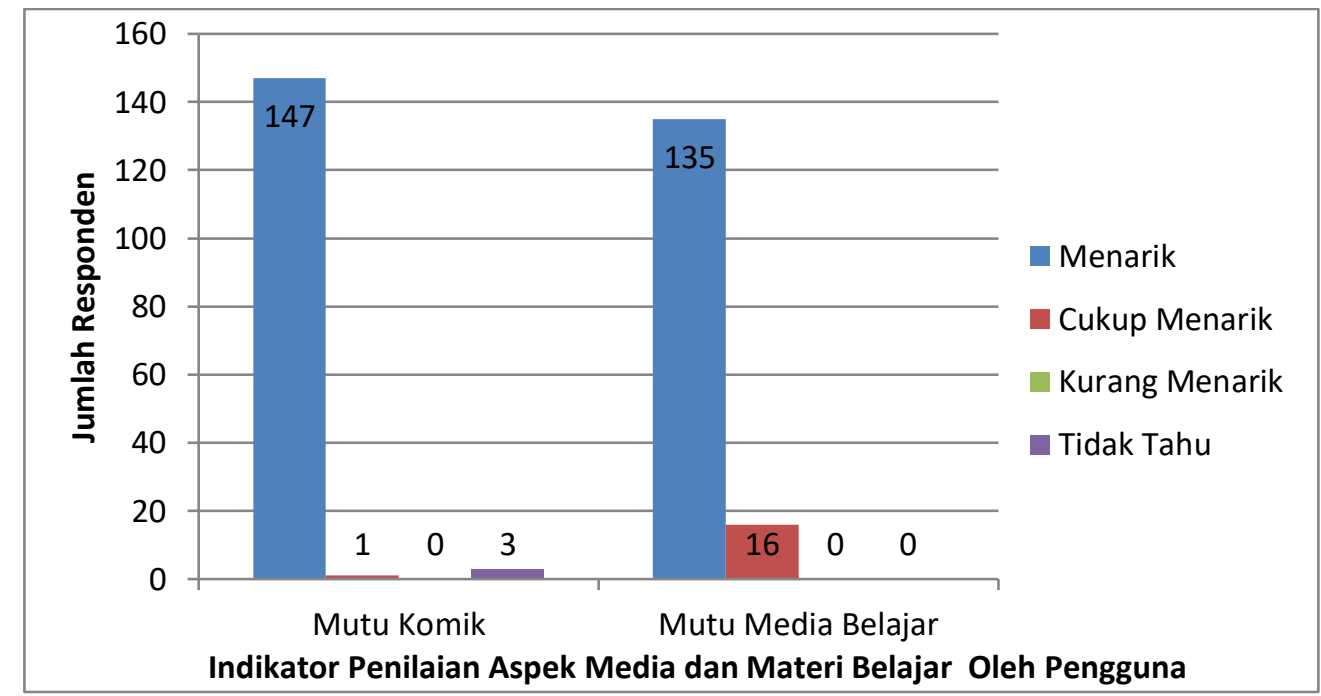

Grafik 1. Penilaian Kelayakan Komik Sebagai Media Belajar Oleh Penggunanya (Peserta Didik)

Didapati bahwa 97\% peserta didik menilai komik menarik, dan $89 \%$ menyatakan bagus digunakan sebagai media belajar. Adapun dimensi dan indikasi motivasi yang digunakan: (a)ketekunan dalam belajar, dilihat dari kehadiran, mengikuti PBM di kelas, aktivitas belajar di luar kelas; (b)sigap dalam belajar, dilihat dari prilaku dalam menghadapi kesulitan, dan usaha mengatasinya; (c)minat dalam belajar, dilihat dari kebiasaan dan fokus dalam belajar; (d)aktif dalam belajar, dilihat dari keinginan untuk mencari tahu dan meraih hasil yang baik; (e)mandiri dalam belajar, dilihat dari penyelesaian tugas dan menggunakan waktu di luar jam pelajaran untuk belajar. Untuk mengetahui motivasi terbangun atau tidak, maka bisa dengan melihat indikasi-indikasi motivasi yang lemah, apakah berkurang atau tidak, ibarat air yang bercampur dengan pasir, untuk mengetahui kadar air kembali murni maka dengan mengecek seberapa besar berkurangnya kandungan pasir di dalam air dari hasil pemisahan keduanya. 


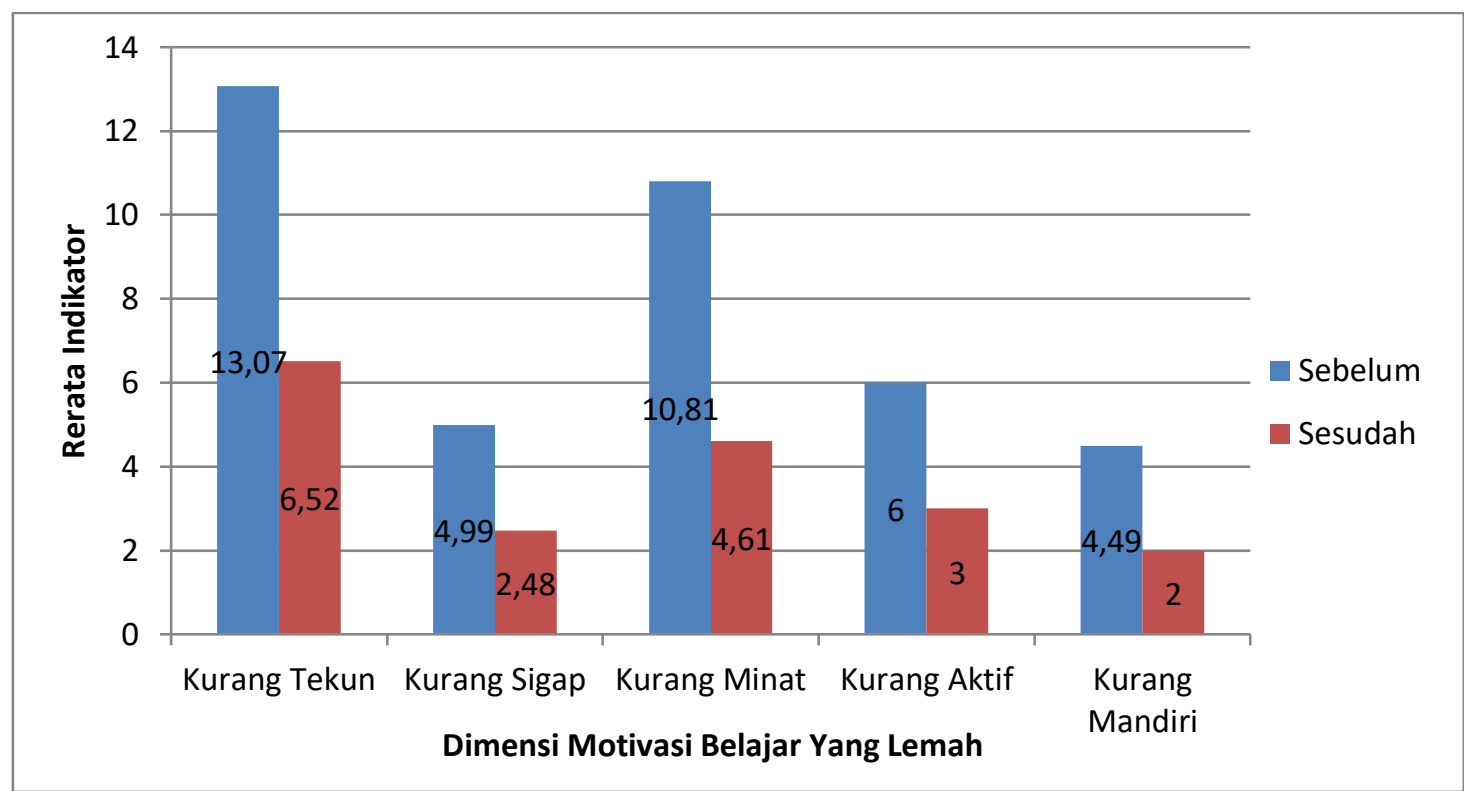

Grafik 2. Penurunan Indikasi Motivasi Belajar Yang Lemah

Berdasarkan pengolahan data angket, diketahui terjadi penurunan indikasi motivasi belajar yang lemah menuju motivasi belajar yang baik. Penurunan indikasi kurang tekun dan kurang sigap diperoleh gain 0.5, adapun penurun indikasi kurang minat, kurang aktif, dan kurang mandiri masing-masing sebesar $0.67,0.33$, dan 0.45 yang semuanya tergolong sedang, ini menunjukkan peserta didik termotivasi. Dan keaktifan siswa dalam pembelajaran, maka $100 \%$ peserta didik mengumpulkan LKPD dalam keadaan terselesaikan dan $90 \%$ terlibat aktif dalam sesi tanya jawab di kelas.

\section{KESIMPULAN}

Kesimpulan hasil penelitian ini ialah pembelajaran aktif dan penggunaan bahan ajar komik mampu membangun motivasi belajar peserta didik, bahkan mendorong mereka meraih hasil belajar yang lebih baik. Hal ini sejalan dengan apa yang dikatakan Sudjana dan Rivai (2011: 68) bahwa komik mampu meningkatkan minat belajar peserta didik.

\section{DAFTAR PUSTAKA}

Abu Ghuddah, A. F. (1996). ar-Rasul al-Mu'allim. Aleppo : Maktabah al-Mathbu'at alIslamiyyah

Anis, I., Muntashar, A. H. (2004). al-Mu'jam al-Wasith. Cairo: Maktabah ash-Syuruq adDauliyyah.

Enawati, E. \& Sari, H. (2010). Pengaruh penggunaan media komik terhadap hasil belajar siswa kelas IX SMA Negeri 3 Pontianak pada materi elektrolit dan non-elektrolit. Jurnal Pendidikan Matematika dan IPA Vol. 1. No.1. pp.24-36.

Eri Barlian. MS. (2016). Metodologi Penelitian Kualitatif \& Kuantitatif. Sukabina Press: Padang. ISBN: 978-602-1650-90-5.

Mudjiman, Haris. (2007). Belajar Mandiri. Surakarta: UNS Press

Sudjana, Nana \& Ahmad Rivai. (2011). Media Pengajaran. Bandung: CV Sinar Baru Algensindo.

Tirmdziy, Abu 'Isa. (2011). Al-Jami' ash-Shahih Sunan at-Tirmidziy. Kairo : Dar Ibn al-Jauziy Waluyanto, H.D. (2005). Komik sebagai media komunikasi visual pembelajaran. Jurnal Nirmana, Vol 7, No 1: Universitas Kristen Petra. 